\title{
PERSPECTIVE
}

\section{Antioxidant therapy in male infertility: fact or fiction?}

\author{
Armand Zini and Naif Al-Hathal
}

Infertile men have higher levels of semen reactive oxygen species (ROS) than do fertile men. High levels of semen ROS can cause sperm dysfunction, sperm DNA damage and reduced male reproductive potential. This observation has led clinicians to treat infertile men with antioxidant supplements. The purpose of this article is to discuss the rationale for antioxidant therapy in infertile men and to evaluate the data on the efficacy of dietary and in vitro antioxidant preparations on sperm function and DNA damage. To date, most clinical studies suggest that dietary antioxidant supplements are beneficial in terms of improving sperm function and DNA integrity. However, the exact mechanism of action of dietary antioxidants and the optimal dietary supplement have not been established. Moreover, most of the clinical studies are small and few have evaluated pregnancy rates. A beneficial effect of in vitro antioxidant supplements in protecting spermatozoa from exogenous oxidants has been demonstrated in most studies; however, the effect of these antioxidants in protecting sperm from endogenous ROS, gentle sperm processing and cryopreservation has not been established conclusively.

Asian Journal of Andrology (2011) 13, 374-381; doi:10.1038/aja.2010.182; published online 25 April 2011

Keywords: antioxidant; male infertility; oxidative stress; sperm DNA fragmentation; vitamins

\section{RELATIONSHIP BETWEEN OXIDATIVE STRESS AND SPERM DYSFUNCTION}

Seminal oxidative stress (OS) results from an imbalance between reactive oxygen species (ROS) production and ROS scavenging by seminal antioxidants. Seminal OS is believed to be one of the main factors in the pathogenesis of sperm dysfunction and sperm DNA damage in male infertility. ${ }^{1-4}$ Indeed, it is estimated that $25 \%$ of infertile men possess high levels of semen ROS, whereas fertile men do not have high levels of semen ROS. ${ }^{1,4-6}$ Although a controlled production of these ROS is required for sperm physiology (sperm hyperactivation, capacitation and acrosome reaction) and for natural fertilization, ${ }^{7-9}$ the excessive production of ROS by immature germ cells and leukocytes causes sperm dysfunction (lipid peroxidation, loss of motility and sperm DNA damage). ${ }^{9,10}$

Spermatozoa are particularly susceptible to oxidative injury due to the abundance of plasma membrane polyunsaturated fatty acids. ${ }^{10-12}$ These unsaturated fatty acids provide fluidity that is necessary for membrane fusion events (e.g., the acrosome reaction and sperm-egg interaction) and for sperm motility. However, the unsaturated nature of these molecules predisposes them to free radical attack and ongoing lipid peroxidation throughout the sperm plasma membrane. Once this process has been initiated, accumulation of lipid peroxides occurs on the sperm surface (this results in loss of sperm motility) and oxidative damage to DNA can ensue. ${ }^{13,14}$

\section{SEMINAL ANTIOXIDANT CAPACITY AND SPERM DYSFUNCTION}

Seminal plasma and spermatozoa themselves are well endowed with an array of protective antioxidants to protect spermatozoa from OS, especially, at the post-testicular level. ${ }^{6,15,16}$ Seminal plasma contains a number of high-molecular weight enzymatic antioxidants (superoxide dismutase, catalase and glutathione peroxidase) and a deficiency in these enzymes has been reported to cause sperm DNA damage and male infertility. ${ }^{1,7,10,17-19}$ Seminal fluid also contains non-enzymatic antioxidants (ascorbic acid, $\alpha$-tocopherol, pyruvate, glutathione, $L$ carnitine, taurine and hypotaurine $)^{20-23}$ which constitute the bulk of seminal antioxidant capacity. In addition, urate, ${ }^{24}$ pyruvate, ${ }^{11,25}$ albumin, beta carotenes and ubiquinol ${ }^{26}$ have been detected in seminal plasma.

A number of investigators have shown that seminal antioxidant capacity is suppressed in infertile men with high ROS levels compared to men with normal levels of ROS. ${ }^{20,27,28}$ However, it is unclear whether reduced semen antioxidant capacity necessarily causes sperm dysfunction (including sperm DNA damage). ${ }^{1,3,29,30}$ Indeed, there is some controversy as to whether the high ROS levels detected in the semen of infertile men are due to increased ROS production, decreased ROS scavenging capacity or both. ${ }^{21,31}$ If the high semen ROS levels are due (at least in part) to a decreased ROS scavenging capacity of semen, it would support the use of dietary antioxidant supplementation. ${ }^{21,31}$

Although a relationship between male infertility and systemic antioxidant deficiency has not been reported to date, it is possible that a subset of infertile men may be at risk for antioxidant deficiency, particularly, vitamin C deficiency. ${ }^{32}$ We suspect that infertile men with specific lifestyles (e.g., smoking, increased alcohol intake and dieting) may be at high risk for antioxidant or vitamin deficiency, but this remains to be tested. ${ }^{33,34}$ Recently, investigators evaluated dietary antioxidant intake (vitamins $\mathrm{C}, \mathrm{E}$ or $\beta$-carotene) and sperm DNA damage in a cohort of fertile men, but failed to identify any relationships between these parameters. ${ }^{35}$ 


\section{TREATMENT OF OXIDATIVE STRESS}

Treatment of oxidative stress should first involve strategies to reduce or eliminate stress-provoking conditions including smoking, varicocele, genital infection, gonadotoxins and hyperthermia. The rationale for treating infertile men with oral antoxidants is based on the premise that seminal oxidative stress (common in infertile men) is due in part to a deficiency in seminal antioxidants. The practice of prescribing oral antioxidant is supported by the lack of serious side effects related to antioxidant therapy, although few studies have carefully evaluated the risk of overtreatment with antioxidants. ${ }^{36}$ Ideally, an oral antioxidant should reach high concentrations in the reproductive tract and replete a deficiency of vital elements important for spermatogenesis. Additionally, the antioxidant supplement should augment the scavenging capacity of seminal plasma and reduce the levels of semen ROS. ${ }^{1}$ However, the levels of semen ROS should not be entirely suppressed (by oral antioxidants) as this may impair normal sperm functions (e.g., sperm capacitation and hyperactivation) that normally require low levels of ROS.,9,19

To date, over 100 clinical and experimental studies have examined the effect of antioxidants on sperm parameters. Despite this large body of literature, it is not possible to establish firm conclusions regarding the optimal antioxidant treatment for infertile men because the published studies report on different types and doses of antioxidants, the studies are small, the end points vary and few of the studies are placebo-controlled. ${ }^{1,6,15}$ Moreover, the presumed mechanism of action of antioxidants in the treatment of male infertility (i.e., suppression of seminal OS) has not been confirmed because few studies have evaluated seminal OS and/or antioxidant capacity before and after treatment. ${ }^{37,38}$

\section{Effect of oral (dietary) antioxidants on sperm dysfunction and DNA damage}

While there is a good body of literature on the effect of oral antioxidants on sperm parameters (including sperm DNA integrity), no study has established the optimal dose, duration of treatment or subpopulation of infertile patients who might benefit most from antioxidant therapy (isolated asthenozoospermia, oligoasthenoteratozoospermia, sperm DNA damage or all). Many small, uncontrolled studies have shown a significant improvement in semen parameters following different doses and types of antioxidant therapy. ${ }^{6,15}$ The most commonly studied oral antioxidants (or antioxidant enzyme cofactors) include vitamin C, vitamin E, selenium, zinc, glutathione, $L$-carnitine and $N$-acetyl cysteine.

The randomized controlled trials (RCTs) on antioxidant therapy for male infertility generally demonstrate that treatment with antioxidants has a beneficial effect (in terms of semen parameter improvements), whereas no significant effect is seen in the placebo group $^{37,39-61}$ (Tables 1 and 2). The variable treatment outcomes in different studies could be due to differences in vitamin dosages, duration of treatment and patient population. ${ }^{6,15}$

One RCT evaluated the effects of vitamin C alone and reported a significant improvement in sperm parameters in the treatment arm only. ${ }^{46}$ Six RCTs evaluated the effects of vitamin $\mathrm{E}$ alone or in combination with vitamin $\mathrm{C}$ or selenium. Two of these studies reported a significant improvement in sperm motility ${ }^{39,41}$ and one reported a significant improvement in sperm DNA integrity ${ }^{59}$ in the treatment arm only. In contrast, three RCTs reported no significant improvement in sperm parameters after vitamin $\mathrm{E} \pm \mathrm{C}$ treatment, ${ }^{56-58}$ although sperm-zona binding improved in one of these studies. ${ }^{56}$ Five RCTs evaluated the effects of zinc alone or in combination with folic acid and all five reported a significant improvement in sperm parameters in the treatment arm only. ${ }^{47,50-55}$ Three RCTs evaluated the effects of selenium alone or in combination with $\mathrm{N}$-acetyl cysteine and two of the three studies reported a significant improvement in sperm parameters in the treatment arm only. ${ }^{43,48,54}$ Four RCTs evaluated the effects of $L$-carnitine alone or in combination with $L$-acetyl carnitine and three of the four reported a significant improvement in sperm parameters in the treatment arm only. ${ }^{42,44,49,60}$ Three RCTs evaluated the effects of $\mathrm{N}$-acetyl cysteine alone or in combination with selenium and all three reported a significant improvement in sperm parameters in the treatment arm only. ${ }^{45,54,61}$

Several investigators have examined the effect of antioxidant therapy on sperm DNA integrity because sperm DNA damage may be caused, at least in part, by oxidative stress. ${ }^{15,22,29,53,62-69}$ In addition, sperm DNA damage is a more reliable outcome measure than sperm concentration or motility because measures of sperm DNA damage exhibit a lower degree of biological variability than conventional semen parameters. ${ }^{70-72}$ Treatment with oral antioxidants has generally been associated with improvement in sperm DNA integrity and in some cases pregnancy rates after assisted reproduction, although most of these studies are small and few are randomized placebo-controlled trials (Table 3). ${ }^{1}$ To date, none of the studies on sperm DNA damage and oral antioxidants have estimated seminal oxidative stress, seminal vitamin levels or used oxidative DNA damage (e.g., by estimation of 8 -hydroxy-2'-deoxyguanosine $(8-\mathrm{OHdG})$ ) as a selection criterion for monitoring the response to antioxidant treatment. ${ }^{1,2,73}$ As such, the precise mechanism of action of these antioxidant supplements on sperm DNA quality is unknown.

\section{Effect of in vitro antioxidants on sperm dysfunction and DNA damage}

The generation of oxidative stress in the in vitro environment, either by direct application of ROS (exogenous) or activation of intrinsic sperm ROS (endogenous), has been associated with clinical evidence of lipid peroxidation, sperm dysfunction and sperm DNA damage. ${ }^{13,14,74-78}$ This is particularly important in the context of in vitro fertilization where seminal plasma is removed during semen processing and the toxic oxygen metabolites (generated by immature spermatozoa and leukocytes) are able to attack spermatozoa without being protected by seminal plasma antioxidants. In addition, the detrimental effect of oxidative stress on sperm functional competence can be exaggerated by the in vitro sperm processing techniques (centrifugation and prolonged incubation) that usually precede assisted reproductive techniques. $^{1,14,75,79}$

\section{ROLE OF IN VITRO ANTIOXIDANTS IN PROTECTING SPERMATOZOA FROM EXOGENOUS ROS}

Attenuating the effects of exogenous ROS is clinically relevant as many of the semen samples from infertile men contain abnormal spermatozoa and leukocytes, and, these cells have the potential to generate exogenous ROS. ${ }^{76}$ Antioxidants such as vitamin E, catalase and glutathione have been shown to protect sperm motility from the effects of exogenous ROS (Table 4). ${ }^{11,80}$ In contrast, superoxide dismutase is less effective in preventing the loss of motility due to exogenous oxidants. ${ }^{11,80}$ Altogether, these data suggest that hydrogen peroxide $\left(\mathrm{H}_{2} \mathrm{O}_{2}\right)$ is the most sperm-toxic ROS. Antioxidants have also been shown to protect the sperm 
Table 1 Summary of studies (RCTs) with positive effect of oral antioxidants on sperm parameters

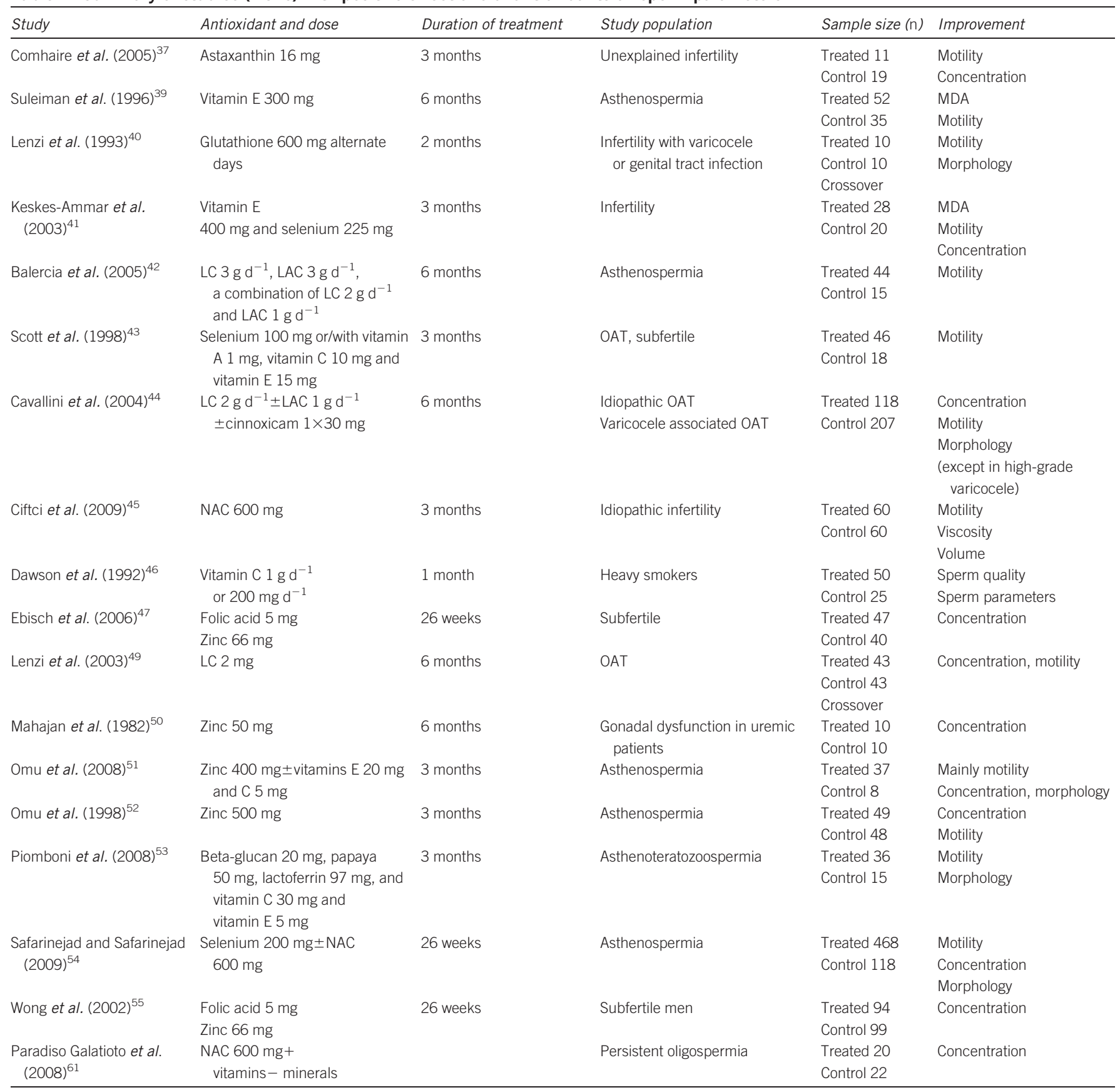

Abbreviations: LC, L-carnitine; LAC, L-acetyl carnitine; MDA, malondialdehyde; NAC, N-acetyl cysteine; OAT, oligoasthenoteratospermia; RCT, randomized controlled trial.

DNA from the effects of exogenous ROS (Table 4). ${ }^{81-84}$ This is highly relevant as sperm DNA damage may impact on reproductive outcomes after assisted reproductive technologies. ${ }^{6}$ Indeed, sperm DNA damage has been associated with reduced pregnancy rates with intrauterine insemination, and, to a lesser extent with conventional in vitro fertilization..$^{5,85,86}$

\section{ROLE OF IN VITRO ANTIOXIDANTS IN PROTECTING SPERMATOZOA FROM ENDOGENOUS ROS}

Spermatozoa can be stimulated to generate ROS using a variety of agents (e.g., NADPH and estrogens) and this ROS production can potentially impair sperm function. ${ }^{87}$ In contrast to the beneficial effect of antioxidants in protecting spermatozoa from exogenous ROS, antioxidants appear to be of limited value in protecting spermatozoa from endogenous ROS production. ${ }^{14}$ Twigg et al. demonstrated that SOD, catalase or both are ineffective, whereas albumin is effective in protecting spermatozoa from loss of motility due to endogenous ROS generation. ${ }^{14}$ These studies stress the importance of using gentle semen processing protocols (e.g., low centrifugation force) so as to minimize the production and adverse impact of endogenous ROS.

Similarly, antioxidants appear to be of limited value in protecting the DNA of normal spermatozoa (with normal chromatin compaction) 
Table 2 Summary of studies (RCTs) with no effect of oral antioxidants on sperm parameters

\begin{tabular}{|c|c|c|c|c|c|}
\hline Study & Antioxidant and dose & Duration of treatment & Study population & Sample size (n) & No improvement \\
\hline Hawkes et al. (2009) ${ }^{48}$ & Selenium $300 \mathrm{mg} \mathrm{d}^{-1}$ & 48 weeks & Normozoospermia & $\begin{array}{l}\text { Treated } 20 \\
\text { Control } 22\end{array}$ & $\begin{array}{l}\text { Motility } \\
\text { Morphology }\end{array}$ \\
\hline Kessopoulou et al. (1995) & Vitamin E $600 \mathrm{mg}$ & 3 months & Infertility with high ROS & $\begin{array}{l}\text { Crossover } \\
\text { Treated and control } 30\end{array}$ & $\begin{array}{l}\text { Concentration, motility } \\
\text { Morphology }\end{array}$ \\
\hline Moilanen et al. $(1993)^{57}$ & Vitamin E $100 \mathrm{mg}$ & 3 months & Unexplained infertility IUI & $\begin{array}{l}\text { Treated } 6 \\
\text { Control } 9\end{array}$ & $\begin{array}{l}\text { Concentration } \\
\text { Motility } \\
\text { Morphology }\end{array}$ \\
\hline Rolf et al. $(1999)^{58}$ & $\begin{array}{l}\text { Vitamin C } 1000 \mathrm{mg} \text {, } \\
\text { vitamin E } 800 \mathrm{mg}\end{array}$ & 56 days & Asthenospermia & $\begin{array}{l}\text { Treated } 15 \\
\text { Control } 16\end{array}$ & $\begin{array}{l}\text { Concentration } \\
\text { Motility } \\
\text { Morphology } \\
\text { Viability }\end{array}$ \\
\hline Greco et al. $(2005)^{59}$ & Vitamins $\mathrm{C}$ and $\mathrm{E}, 1 \mathrm{~g} \mathrm{~d}^{-1}$ & 2 months & Idiopathic infertility & $\begin{array}{l}\text { Treated } 32 \\
\text { Control } 32\end{array}$ & $\begin{array}{l}\text { Concentration } \\
\text { Motility } \\
\text { Morphology }\end{array}$ \\
\hline Sigman et al. $(2006)^{60}$ & $\begin{array}{l}\text { Carnitine } 1000 \text { mg, } \\
\text { L-acetyl carnitine } 500 \mathrm{mg}\end{array}$ & 24 weeks & Asthenospermia & $\begin{array}{l}\text { Treated } 12 \\
\text { Control } 9\end{array}$ & Motility \\
\hline
\end{tabular}

Abbreviations: IUI, intrauterine insemination; RCT, randomized controlled trial; ROS, reactive oxygen species.

Table 3 Effect of dietary antioxidant supplements on sperm DNA integrity

\begin{tabular}{|c|c|c|c|c|}
\hline Study & Patients/test & Treatment(s) & Sample size (n) & Results \\
\hline \multicolumn{5}{|c|}{ Infertile men with high sperm DNA fragmentation levels or oxidative stress } \\
\hline \multirow[t]{2}{*}{ Greco et al. $(2005)^{59}$} & Infertility & \multirow[t]{2}{*}{ Vits C $1 \mathrm{~g}, \mathrm{E} 1 \mathrm{~g}$} & 32 & Rx (2 months): $\downarrow D D(22 \% \rightarrow 9 \%)$ \\
\hline & TUNEL $>15 \%$ & & 32 & Placebo group: no effect on DD (22\%-22\%) \\
\hline Greco et al. $(2005)^{63}$ & $\begin{array}{l}1 \text { failed ICSI } \\
\text { TUNEL }>15 \%\end{array}$ & Vits C $1 \mathrm{~g}, \mathrm{E} 1 \mathrm{~g}$ & 38 & $\begin{array}{l}\text { Rx ( } 2 \text { months): } \downarrow \text { DD in } 76 \%, 48 \% \text { ICSI pregnancy } \\
\text { No control group }\end{array}$ \\
\hline Tremellen et al. $(2007)^{67}$ & $\begin{array}{l}\text { Male infertility } \\
\text { TUNEL }>25 \%\end{array}$ & $\begin{array}{l}\text { Menevit (lycopene, vits C, } \\
\text { E, zinc, Se, folate, garlic) }\end{array}$ & $\begin{array}{l}36 \\
16\end{array}$ & $\begin{array}{l}\text { Rx ( } 3 \text { months): } 39 \% \text { ICSI pregnancy rate, but no } \uparrow \text { in embryo quality, no post-Rx DD } \\
\text { Placebo group: } 16 \% \text { ICSI pregnancy rate }\end{array}$ \\
\hline Tunc et al. (2009) 68 & $\begin{array}{l}\text { Male infertility } \\
\uparrow \text { Semen OS }\end{array}$ & $\begin{array}{l}\text { Menevit (lycopene, vits C, } \\
\text { E, zinc, Se, folate, garlic) }\end{array}$ & 45 & $\begin{array}{l}\mathrm{Rx}(3 \text { months): } \downarrow \mathrm{DD}(22 \% \rightarrow 18 \%), \downarrow R O S \text { production and } \uparrow \text { sperm protamination } \\
\text { No control group }\end{array}$ \\
\hline \multicolumn{5}{|l|}{ Unselected infertile men } \\
\hline
\end{tabular}

Abbreviations: 8-OHdG, 8-hydroxy-2'-deoxyguanosine; AO, acridine orange; DD, DNA damage; Decond, decondensation; DFI, DNA fragmentation index; LPO, lipid peroxidation; OS, oxidative stress; Rx, treatment; ROS, reactive oxygen species; Se, selenium; TUNEL, terminal nucleotidyl transferase-mediated dUTP nick end labeling; vit, vitamin.

Table 4 Role of in vitro antioxidants in protecting spermatozoa from the loss of motility and DNA damage due to exogenous ROS

\begin{tabular}{|c|c|c|}
\hline Study & Exogenous ROS & Antioxidant supplement and results \\
\hline \multicolumn{3}{|l|}{ Sperm motility } \\
\hline de Lamirande and Gagnon (1992) ${ }^{11}$ & $\mathrm{X}+\mathrm{XO}$ & $\begin{array}{l}\text { Catalase protects sperm from } X+X O \text {-induced loss of motility } \\
\text { SOD, DTT or GSH less effective in protecting sperm motility from ROS }\end{array}$ \\
\hline \multicolumn{3}{|r|}{ 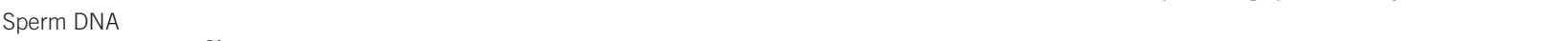 } \\
\hline Lopes et al. $(1998)^{81}$ & $\mathrm{X}+\mathrm{XO}$ & $\begin{array}{l}\text { GSH+hypotaurine protect sperm from } \mathrm{X}+\mathrm{XO} \text {-induced } \mathrm{DD} \\
\text { Catalase protects sperm from } \mathrm{X}+\mathrm{XO} \text {-induced } \mathrm{DD} \\
\mathrm{N} \text {-acetylcysteine protects sperm from } \mathrm{X}+\mathrm{XO} \text {-induced } \mathrm{DD}\end{array}$ \\
\hline Potts et al. $(2000)^{82}$ & $\mathrm{H}_{2} \mathrm{O}_{2}+\mathrm{Fe}+\mathrm{ADP}$ & Seminal plasma ( $>60 \% \mathrm{v} / \mathrm{v}$ ) lowers oxidative sperm damage ( $\downarrow D D, L P O)$ \\
\hline Russo et al. (2006) ${ }^{83}$ & $\begin{array}{l}\mathrm{H}_{2} \mathrm{O}_{2} \\
\text { Benzopyrene } \\
\mathrm{H}_{2} \mathrm{O}_{2}+\mathrm{Fe}+\mathrm{ADP}\end{array}$ & $\begin{array}{l}\text { Propolis lowers oxidative sperm damage ( } \downarrow \text { LPO, DD, LDH) } \\
\quad \text { (Propolis—a natural resinous hive product) }\end{array}$ \\
\hline Sierens et al. (2002) $)^{84}$ & $\mathrm{H}_{2} \mathrm{O}_{2}$ & $\begin{array}{l}\text { Isoflavones, vitamins } \mathrm{C} \text { and } \mathrm{E} \text { protect sperm from } \mathrm{H}_{2} \mathrm{O}_{2} \text {-induced DD } \\
\text { (isoflavones: genistein, equol). Dose effect noted. }\end{array}$ \\
\hline
\end{tabular}

Abbreviations: ADP, adenosine diphosphate; DD, DNA damage; GSH, glutathione; LDH, lactate dehydrogenase; LPO, lipid peroxidation; $X$, xanthine; XO, xanthine oxidase. 
from endogenous ROS production (e.g., NADPH-induced or centrifugation-induced). ${ }^{14,77,88,89}$ In samples with poor morphology and poor sperm chromatin compaction, antioxidants may protect the sperm DNA from endogenous ROS production, as these samples are more vulnerable to oxidative stress. ${ }^{90,91}$ In support of these clinical observations, experimental (animal) studies suggest that the spermatozoa of infertile men may be more susceptible to oxidative injury in vitro but benefit more so from antioxidants than the spermatozoa of fertile men. $^{92}$

\section{ROLE OF IN VITRO ANTIOXIDANTS IN PROTECTING SPERMATOZOA FROM SEMEN PROCESSING}

Several studies have reported on the effects of antioxidants in preventing the decline in sperm motility after semen processing and incubation (Table 5). These studies have clinical relevance because it is important to maximize sperm motility prior to assisted reproductive techniques such as intrauterine insemination and standard in vitro fertilization. The available studies report conflicting results regarding the effects of antioxidants in preventing the loss of sperm motility during sperm processing such as centrifugation and incubation. Some studies have shown that antioxidants (e.g., vitamin E, glutathione, $\mathrm{N}$-acetyl cysteine, catalase and ferulic acid) are effective in reducing ROS levels and in preventing the decline in sperm motility during sperm processing. ${ }^{93-96}$ In contrast, other studies have reported that antioxidants (e.g., glutathione and catalase) are ineffective in protecting spermatozoa from the loss of motility during sperm processing. ${ }^{97-99}$ It is important to note that sperm samples from infertile men may be more susceptible to oxidative injury (from semen processing) and be afforded greater protection by antioxidants than samples from fertile men. ${ }^{92}$

Antioxidants appear to be of limited value in protecting sperm DNA from gentle semen processing (e.g., incubation or densitygradient centrifugation) (Table 5). ${ }^{98-101}$ In some cases, antioxidants supplementation in vitro (e.g., combination of vitamins $\mathrm{C}$ and $\mathrm{E}$ ) may cause sperm DNA damage. ${ }^{99,101}$

\section{ROLE OF IN VITRO ANTIOXIDANTS IN PROTECTING SPERMATOZOA FROM CRYOPRESERVATION AND THAWING}

Several studies have evaluated the role of antioxidants in protecting spermatozoa from the loss of motility that occurs following cryopreservation and thawing. Most studies have reported on the use of pentoxifilline (an antioxidant and phosphodiesterase inhibitor). Some studies have shown that pentoxifilline improves post-thaw sperm motility and/or sperm function, ${ }^{102-105}$ whereas others have demonstrated that this antioxidant does not have a beneficial effect. ${ }^{106}$ Other antioxidants (vitamins $\mathrm{E}$ and $\mathrm{C}$ and rebamipide) have been used to enhance post-thaw motility; however, the results have been modest. ${ }^{107,108}$ Several studies have also examined the role of antioxidants in protecting sperm DNA from injury following cryopreservation and thawing. Most studies have shown that antioxidants (vitamin C, catalase, resveratrol and genistein) can protect the sperm DNA from oxidative injury during cryopreservation and subsequent thawing ${ }^{109-112}$ (Table 6). In contrast, Taylor et al. reported that the antioxidant vitamin E does not protect sperm DNA during cryopreservation. ${ }^{13}$

Taken together, the data suggest that antioxidants are generally effective in protecting spermatozoa from the effects of cryopreservation and thawing. However, the technique of cryopreservation and

Table 5 The effect of in vitro antioxidants on sperm motility and DNA integrity during semen processing

\begin{tabular}{|c|c|c|c|}
\hline Study & Parameter & Semen processing & Antioxidant supplement and results \\
\hline \multicolumn{4}{|l|}{ Motility } \\
\hline Griveau and Le Lannou (1994) ${ }^{93}$ & Motility & $\begin{array}{l}\text { CF at } 400 g \times 2 \\
\text { Swim-up }\end{array}$ & DTT, catalase, SOD or GSH improve motility \\
\hline Oeda et al. $(1997)^{94}$ & $\begin{array}{l}\text { Motility } \\
\text { ROS }\end{array}$ & $2 \mathrm{~h}$ incubation & $\begin{array}{l}\text { NAC lowers semen ROS levels } \\
\text { NAC improves sperm motility }\end{array}$ \\
\hline Verma and Kanwar (1999) ${ }^{95}$ & $\begin{array}{l}\text { Motility } \\
\text { LPO }\end{array}$ & $6 \mathrm{~h}$ incubation & Vitamin E lowers sperm LPO and protects spermatozoa from loss of motility \\
\hline Zheng and Zhang (1997) ${ }^{96}$ & $\begin{array}{l}\text { Motility } \\
\text { LPO }\end{array}$ & $\begin{array}{l}2 \text { and } 3 \mathrm{~h} \text { incubation } \\
\text { (fertile and infertile) }\end{array}$ & $\begin{array}{l}\text { Ferulic acid improves sperm motility and reduces LPO } \\
\text { Ferulic acid increases sperm cAMP and cGMP }\end{array}$ \\
\hline Calamera et al. $(2001)^{97}$ & $\begin{array}{l}\text { Motility } \\
\text { ROS }\end{array}$ & $2-47 \mathrm{~h}$ incubation & Catalase did not protect spermatozoa from loss of motility \\
\hline Chi et al. (2008) ${ }^{98}$ & $\begin{array}{l}\text { Motility } \\
\text { ROS }\end{array}$ & $\begin{array}{l}\text { Centrifugation (1000 rpm } \mathrm{min}^{-1} \\
\times 2)+1 \mathrm{~h} \text { incubation }\end{array}$ & $\begin{array}{l}\text { EDTA or catalase lower CF-induced sperm ROS } \\
\text { EDTA (but not catalase) protects spermatozoa from CF-induced loss sperm motility }\end{array}$ \\
\hline Donnelly et al. $(2000)^{99}$ & Motility & Percoll DGC $+4 \mathrm{~h}$ incubation & GSH or hypotaurine do not protect spermatozoa from loss of motility \\
\hline \multicolumn{4}{|l|}{ DNA integrity } \\
\hline Chi et al. (2008) $)^{98}$ & COMET & $\begin{array}{l}\text { Centrifugation (1000 rpm } \mathrm{min}^{-1} \\
\times 2)+1 \mathrm{~h} \text { incubation }\end{array}$ & $\begin{array}{l}\text { EDTA or catalase lower centrifugation-induced sperm ROS } \\
\text { EDTA or catalase lower centrifugation-induced sperm DD } \\
\text { EDTA or catalase have no protective effect on LPO }\end{array}$ \\
\hline Donnelly et al. $(2000)^{99}$ & COMET & Percoll DGC $\pm \mathrm{H}_{2} \mathrm{O}_{2}$ & $\begin{array}{l}\mathrm{GSH} \text {, hypotaurine or both do not alter baseline sperm DD } \\
\mathrm{GSH} \text {, hypotaurine or both do not alter sperm motility at } 4 \mathrm{~h} \\
\mathrm{GSH} \text { and/or hypotaurine lower } \mathrm{H}_{2} \mathrm{O}_{2} \text {-induced sperm DD }\end{array}$ \\
\hline Donnelly et al. (1999) 100 & COMET & Percoll DGC & $\begin{array}{l}\text { Vitamin } \mathrm{C} \text { or } \mathrm{E} \text { do not lower baseline sperm ROS and DD } \\
\text { Vitamin } \mathrm{C} \text { or } \mathrm{E} \text { protect sperm from } \mathrm{H}_{2} \mathrm{O}_{2} \text { induced ROS and DD } \\
\text { Vitamins } \mathrm{C}+\mathrm{E} \text { induce sperm DD and increase } \mathrm{H}_{2} \mathrm{O}_{2} \text {-induced DD }\end{array}$ \\
\hline Hughes et al. (1998) ${ }^{101}$ & COMET & Percoll DGC & $\begin{array}{l}\text { Vitamins } C, E \text { or urate lower sperm DD after DGC } \\
\text { Vitamins } C+E \text { or AC increase sperm DD after DGC }\end{array}$ \\
\hline
\end{tabular}

Abbreviations: AC, acetyl cysteine; CF, centrifugation; COMET, alkaline single-cell gel electrophoresis; DD, DNA damage; DGC, density-gradient centrifugation; DTT, dithiotreitol; GSH, glutathione; LPO, lipid peroxidation; NAC, N-acetyl-L-cysteine; ROS, reactive oxygen species; SOD, superoxide dismutase. 
Table 6 The role of in vitro antioxidants in protecting human sperm DNA from injury caused by cryopreservation and thawing

\begin{tabular}{|c|c|c|c|}
\hline Study & Assay & Antioxidant & $\begin{array}{l}\text { Effect of antioxidant on cryopreservation and } \\
\text { thawing }\end{array}$ \\
\hline Branco et al. $(2009)^{109}$ & COMET & Resveratol or ascorbic acid & Improved sperm DNA integrity \\
\hline Li et al. $(2009)^{110}$ & COMET & Catalase or ascorbic acid & $\begin{array}{l}\text { Improved sperm DNA integrity } \\
\text { Reduced ROS production }\end{array}$ \\
\hline Martinez-Soto et al. (2009) $)^{111}$ & TUNEL & Genistein & $\begin{array}{l}\text { Improved sperm DNA integrity } \\
\text { Reduced ROS production } \\
\text { Improved post-thaw motility }\end{array}$ \\
\hline Taylor et al. (2009) & TUNEL & Vitamin E & $\begin{array}{l}\text { No effect on sperm DNA integrity } \\
\text { Improved post-thaw motility }\end{array}$ \\
\hline
\end{tabular}

Abbreviations: 8-OHdG, 8-hydroxy-2'-deoxyguanosine; COMET, alkaline single cell gel electrophoresis; ROS, reactive oxygen species; TUNEL, terminal nucleotidyl transferase-mediated dUTP nick end labeling.

type of cryoprotectant are also important in improving post-thaw sperm function. ${ }^{114}$

\section{SUMMARY}

Oxidative stress plays an important role in the pathophysiology of male infertility. The published studies on dietary antioxidants (including randomized, placebo-controlled trials) generally demonstrate a beneficial effect of antioxidants on sperm function. However, the mechanism of action of these antioxidants as well as the optimal type and dosage of antioxidant is unknown. The study of in vitro antioxidants is highly relevant in the era of assisted reproduction because of the susceptibility of human spermatozoa to oxidative injury and the vulnerability of these cells during semen processing. Most studies have demonstrated a beneficial effect of in vitro antioxidant supplements in protecting spermatozoa from exogenous oxidants and cryopreservation (with subsequent thawing). In contrast, the effect of these antioxidants in protecting normal spermatozoa from endogenous ROS and gentle sperm processing has not been established conclusively. Additional studies are needed to determine the optimal antioxidant preparation to protect spermatozoa from oxidative stress in vitro.

\section{COMPETING FINANCIAL INTERESTS}

Dr Armand Zini is a shareholder in YAD technologies Inc. (a nutraceutical supplement company).

1 Zini A, San Gabriel M, Baazeem A. Antioxidants and sperm DNA damage: a clinical perspective. J Assist Reprod Genet 2009; 26: 427-32.

2 Aitken RJ, de Iuliis GN, Finnie JM, Hedges A, McLachlan RI. Analysis of the relationships between oxidative stress, DNA damage and sperm vitality in a patient population: development of diagnostic criteria. Hum Reprod 2010; 25: 2415-26.

3 Fraga CG, Motchnik PA, Shigenaga MK, Helbock HJ, Jacob RA et al. Ascorbic acid protects against endogenous oxidative DNA damage in human sperm. Proc Natl Acad Sci USA 1991; 88: 11003-6.

4 Iwasaki A, Gagnon C. Formation of reactive oxygen species in spermatozoa of infertile patients. Fertil Steril 1992; 57: 409-16.

5 Zini A, Sigman M. Are tests of sperm DNA damage clinically useful? Pros and cons. $J$ Androl 2009; 30: 219-29.

6 Agarwal A, Nallella KP, Allamaneni SS, Said TM. Role of antioxidants in treatment of male infertility: an overview of the literature. Reprod Biomed Online 2004; 8: 61627.

7 Aitken RJ, Paterson M, Fisher H, Buckingham DW, van Duin M. Redox regulation of tyrosine phosphorylation in human spermatozoa and its role in the control of human sperm function. J Cell Sci 1995; 108 (Pt 5): 2017-25.

8 Griveau JF, Le Lannou D. Reactive oxygen species and human spermatozoa: physiology and pathology. Int J Androl 1997; 20: 61-9.

9 de Lamirande $\mathrm{E}$, Jiang $\mathrm{H}$, Zini A, Kodama H, Gagnon C. Reactive oxygen species and sperm physiology. Rev Reprod 1997; 2: 48-54.
10 Aitken RJ, Clarkson JS. Cellular basis of defective sperm function and its association with the genesis of reactive oxygen species by human spermatozoa. $J$ Reprod Fertil 1987; 81: 459-69.

11 de Lamirande E, Gagnon C. Reactive oxygen species and human spermatozoa. I. Effects on the motility of intact spermatozoa and on sperm axonemes. $J$ Androl 1992; 13: 368-78.

12 Zini A, Garrels K, Phang D. Antioxidant activity in the semen of fertile and infertile men. Urology 2000; 55: 922-6.

13 Alvarez JG, Touchstone JC, Blasco L, Storey BT. Spontaneous lipid peroxidation and production of hydrogen peroxide and superoxide in human spermatozoa. Superoxide dismutase as major enzyme protectant against oxygen toxicity. J Androl 1987; 8: 338-48.

14 Twigg J, Fulton N, Gomez E, Irvine DS, Aitken RJ. Analysis of the impact of intracellular reactive oxygen species generation on the structural and functional integrity of human spermatozoa: lipid peroxidation, DNA fragmentation and effectiveness of antioxidants. Hum Reprod 1998; 13: 1429-36.

15 Tremellen K. Oxidative stress and male infertility-a clinical perspective. Hum Reprod Update 2008; 14: 243-58.

16 Saleh RA, Agarwal A. Oxidative stress and male infertility: from research bench to clinical practice. J Androl 2002; 23: 737-52.

17 Chabory E, Damon C, Lenoir A, Kauselmann G, Kern H et al. Epididymis selenoindependent glutathione peroxidase 5 maintains sperm DNA integrity in mice. J Clin Invest 2009; 119: 2074-85.

18 Weir CP, Robaire B. Spermatozoa have decreased antioxidant enzymatic capacity and increased reactive oxygen species production during aging in the Brown Norway rat. J Androl 2007; 28: 229-40.

19 Zini A, de Lamirande E, Gagnon C. Low levels of nitric oxide promote human sperm capacitation in vitro. J Androl 1995; 16: 424-31.

20 Smith R, Vantman D, Ponce J, Escobar J, Lissi E. Total antioxidant capacity of human seminal plasma. Hum Reprod 1996; 11: 1655-60.

21 Zini A, de Lamirande E, Gagnon C. Reactive oxygen species in semen of infertile patients: levels of superoxide dismutase- and catalase-like activities in seminal plasma and spermatozoa. Int J Androl 1993; 16: 183-8.

22 Kobayashi T, Miyazaki T, Natori M, Nozawa S. Protective role of superoxide dismutase in human sperm motility: superoxide dismutase activity and lipid peroxide in human seminal plasma and spermatozoa. Hum Reprod 1991; 6: 987-91.

23 Zini A, Schlegel PN. Catalase mRNA expression in the male rat reproductive tract. J Androl 1996; 17: 473-80.

24 Thiele JJ, Friesleben HJ, Fuchs J, Ochsendorf FR. Ascorbic acid and urate in human seminal plasma: determination and interrelationships with chemiluminescence in washed semen. Hum Reprod 1995; 10: 110-5.

25 Kalthur G, Adiga SK, Upadhya D, Rao S, Kumar P. Effect of cryopreservation on sperm DNA integrity in patients with teratospermia. Fertil Steril 2008; 89: 1723-7.

26 Tauber PF, Zaneveld LJ, Propping D, Schumacher GF. Components of human split ejaculates. I. Spermatozoa, fructose, immunoglobulins, albumin, lactoferrin, transferrin and other plasma proteins. J Reprod Fertil 1975; 43: 249-67.

27 Lewis SE, Sterling ES, Young IS, Thompson W. Comparison of individual antioxidants of sperm and seminal plasma in fertile and infertile men. Fertil Steril 1997; 67 142-7.

28 Sanocka D, Miesel R, Jedrzejczak P, Kurpisz MK. Oxidative stress and male infertility. J Androl 1996; 17: 449-54.

29 Appasamy M, Muttukrishna S, Pizzey AR, Ozturk O, Groome NP et al. Relationship between male reproductive hormones, sperm DNA damage and markers of oxidative stress in infertility. Reprod Biomed Online 2007; 14: 159-65.

30 Verit FF, Verit A, Kocyigit A, Ciftci $\mathrm{H}$, Celik $\mathrm{H}$ et al. No increase in sperm DNA damage and seminal oxidative stress in patients with idiopathic infertility. Arch Gynecol Obstet 2006; 274: 339-44

31 Lewis SE, Boyle PM, McKinney KA, Young IS, Thompson W. Total antioxidant capacity of seminal plasma is different in fertile and infertile men. Fertil Steril 1995; 64 868-70. 
32 Hampl JS, Taylor CA, Johnston CS. Vitamin C deficiency and depletion in the United States: the Third National Health and Nutrition Examination Survey, 1988 to 1994. Am J Public Health 2004; 94: 870-5.

33 Jacob RA. Assessment of human vitamin C status. J Nutr 1990; 120 (Suppl 11): $1480-5$.

34 Ryle PR, Thomson AD. Nutrition and vitamins in alcoholism. Contemp Issues Clin Biochem 1984; 1: 188-224.

35 Silver EW, Eskenazi B, Evenson DP, Block G, Young S et al. Effect of antioxidant intake on sperm chromatin stability in healthy nonsmoking men. J Androl 2005; 26: 550-6.

36 Henkel RR. Leukocytes and oxidative stress: dilemma for sperm function and male fertility. Asian J Androl 2011; 13: 43-52.

37 Comhaire FH, El Garem Y, Mahmoud A, Eertmans F, Schoonjans F. Combined conventional/antioxidant "Astaxanthin" treatment for male infertility: a double blind, randomized trial. Asian J Androl 2005; 7: 257-62.

38 Comhaire FH, Christophe AB, Zalata AA, Dhooge WS, Mahmoud AM et al. The effects of combined conventional treatment, oral antioxidants and essential fatty acids on sperm biology in subfertile men. Prostaglandins Leukot Essent Fatty Acids 2000; 63: 159-65.

39 Suleiman SA, Ali ME, Zaki ZM, el-Malik EM, Nasr MA. Lipid peroxidation and human sperm motility: protective role of vitamin E. J Andro/1996; 17: 530-7.

40 Lenzi A, Culasso F, Gandini L, Lombardo F, Dondero F. Placebo-controlled, doubleblind, cross-over trial of glutathione therapy in male infertility. Hum Reprod 1993; 8: 1657-62.

41 Keskes-Ammar L, Feki-Chakroun N, Rebai T, Sahnoun Z, Ghozzi H et al. Sperm oxidative stress and the effect of an oral vitamin $E$ and selenium supplement on semen quality in infertile men. Arch Androl 2003; 49: 83-94.

42 Balercia G, Regoli F, Armeni T, Koverech A, Mantero F et al. Placebo-controlled double-blind randomized trial on the use of $L$-carnitine, $L$-acetylcarnitine, or combined $L$-carnitine and $L$-acetylcarnitine in men with idiopathic asthenozoospermia. Fertil Steril 2005; 84: 662-71.

43 Scott R, MacPherson A, Yates RW, Hussain B, Dixon J. The effect of oral selenium supplementation on human sperm motility. Br J Urol 1998; 82: 76-80.

44 Cavallini G, Ferraretti AP, Gianaroli L, Biagiotti G, Vitali G. Cinnoxicam and Lcarnitine/acetyl-L-carnitine treatment for idiopathic and varicocele-associated oligoasthenospermia. J Androl 2004; 25: 761-70; discussion 71-2.

45 Ciftci $\mathrm{H}$, Verit A, Savas M, Yeni E, Erel O. Effects of $\mathrm{N}$-acetylcysteine on semen parameters and oxidative/antioxidant status. Urology 2009; 74: 73-6.

46 Dawson EB, Harris WA, Teter MC, Powell LC. Effect of ascorbic acid supplementation on the sperm quality of smokers. Fertil Steril 1992; 58: 1034-9.

47 Ebisch IM, Pierik FH, de Jong FH, Thomas CM, Steegers-Theunissen RP. Does folic acid and zinc sulphate intervention affect endocrine parameters and sperm characteristics in men? Int J Androl 2006; 29: 339-45.

48 Hawkes WC, Alkan Z, Wong K. Selenium supplementation does not affect testicular selenium status or semen quality in North American men. J Androl 2009; 30: 525-33.

49 Lenzi A, Lombardo F, Sgro P, Salacone P, Caponecchia L et al. Use of carnitine therapy in selected cases of male factor infertility: a double-blind crossover trial. Fertil Steril 2003; 79: 292-300.

50 Mahajan SK, Abbasi AA, Prasad AS, Rabbani P, Briggs WA et al. Effect of oral zinc therapy on gonadal function in hemodialysis patients. A double-blind study. Ann Intern Med 1982; 97: 357-61.

51 Omu AE, Al-Azemi MK, Kehinde EO, Anim JT, Oriowo MA et al. Indications of the mechanisms involved in improved sperm parameters by zinc therapy. Med Princ Pract 2008; 17: 108-16.

52 Omu AE, Dashti H, Al-Othman S. Treatment of asthenozoospermia with zinc sulphate: andrological, immunological and obstetric outcome. Eur J Obstet Gynecol Reprod Biol 1998; 79: 179-84

53 Piomboni P, Gambera L, Serafini F, Campanella G, Morgante G et al. Sperm quality improvement after natural anti-oxidant treatment of asthenoteratospermic men with leukocytospermia. Asian J Androl 2008; 10: 201-6.

54 Safarinejad MR, Safarinejad S. Efficacy of selenium and/or $\mathrm{N}$-acetyl-cysteine for improving semen parameters in infertile men: a double-blind, placebo controlled, randomized study. J Urol 2009; 181: 741-51.

55 Wong WY, Merkus HM, Thomas CM, Menkveld R, Zielhuis GA et al. Effects of folic acid and zinc sulfate on male factor subfertility: a double-blind, randomized, placebocontrolled trial. Fertil Steril 2002; 77: 491-8.

56 Kessopoulou E, Powers HJ, Sharma KK, Pearson MJ, Russell JM et al. A double-blind randomized placebo cross-over controlled trial using the antioxidant vitamin $\mathrm{E}$ to treat reactive oxygen species associated male infertility. Fertil Steril 1995; 64: 825-31.

57 Moilanen J, Hovatta O, Lindroth L. Vitamin E levels in seminal plasma can be elevated by oral administration of vitamin $\mathrm{E}$ in infertile men. Int J Androl 1993; 16: 165-6.

58 Rolf C, Cooper TG, Yeung $\mathrm{CH}$, Nieschlag E. Antioxidant treatment of patients with asthenozoospermia or moderate oligoasthenozoospermia with high-dose vitamin $\mathrm{C}$ and vitamin E: a randomized, placebo-controlled, double-blind study. Hum Reprod 1999; 14: 1028-33.

59 Greco E, lacobelli M, Rienzi L, Ubaldi F, Ferrero S et al. Reduction of the incidence of sperm DNA fragmentation by oral antioxidant treatment. J Androl 2005; 26: 349-53.

60 Sigman M, Glass S, Campagnone J, Pryor JL. Carnitine for the treatment of idiopathic asthenospermia: a randomized, double-blind, placebo-controlled trial. Fertil Steril 2006; 85: 1409-14.

61 Paradiso Galatioto G, Gravina GL, Angelozzi G, Sacchetti A, Innominato PF et al. May antioxidant therapy improve sperm parameters of men with persistent oligospermia after retrograde embolization for varicocele? World J Urol 2008; 26: 97-102.
62 Gil-Villa AM, Cardona-Maya W, Agarwal A, Sharma R, Cadavid A. Role of male factor in early recurrent embryo loss: do antioxidants have any effect? Fertil Steril 2009; 92: 565-71.

63 Greco E, Romano S, lacobelli M, Ferrero S, Baroni E et al. ICSI in cases of sperm DNA damage: beneficial effect of oral antioxidant treatment. Hum Reprod 2005; 20: 2590-4.

64 Greco E, Scarselli F, lacobelli M, Rienzi L, Ubaldi F et al. Efficient treatment of infertility due to sperm DNA damage by ICSI with testicular spermatozoa. Hum Reprod 2005; 20: 226-30.

65 Kodama H, Yamaguchi R, Fukuda J, Kasai H, Tanaka T. Increased oxidative deoxyribonucleic acid damage in the spermatozoa of infertile male patients. Fertil Steril 1997; 68: 519-24.

66 Menezo YJ, Hazout A, Panteix G, Robert F, Rollet J et al. Antioxidants to reduce sperm DNA fragmentation: an unexpected adverse effect. Reprod Biomed Online 2007; 14: 418-21.

67 Tremellen K, Miari G, Froiland D, Thompson J. A randomised control trial examining the effect of an antioxidant (Menevit) on pregnancy outcome during IVF-ICSI treatment. Aust NZ J Obstet Gynaecol 2007; 47: 216-21.

68 Tunc 0, Thompson J, Tremellen K. Improvement in sperm DNA quality using an oral antioxidant therapy. Reprod Biomed Online 2009; 18: 761-8.

69 Steenken S. Structure, acid/base properties and transformation reactions of purine radicals. Free Radic Res Commun 1989; 6: 117-20.

70 Zini A, Kamal K, Phang D, Willis J, Jarvi K. Biologic variability of sperm DNA denaturation in infertile men. Urology 2001; 58: 258-61.

71 Smit M, Dohle GR, Hop WC, Wildhagen MF, Weber RF et al. Clinical correlates of the biological variation of sperm DNA fragmentation in infertile men attending an andrology outpatient clinic. Int J Androl 2007; 30: 48-55.

72 Evenson DP, Jost LK, Baer RK, Turner TW, Schrader SM. Individuality of DNA denaturation patterns in human sperm as measured by the sperm chromatin structure assay. Reprod Toxicol 1991; 5: 115-25.

73 de luliis GN, Thomson LK, Mitchell LA, Finnie JM, Koppers AJ et al. DNA damage in human spermatozoa is highly correlated with the efficiency of chromatin remodeling and the formation of 8-hydroxy-2'-deoxyguanosine, a marker of oxidative stress. Biol Reprod 2007; 81: 517-24.

74 Aitken RJ, Clarkson JS, Fishel S. Generation of reactive oxygen species, lipid peroxidation, and human sperm function. Biol Reprod 1989; 41: 183-97.

75 Aitken RJ, Baker HW. Seminal leukocytes: passengers, terrorists or good samaritans? Hum Reprod 1995; 10: 1736-9.

76 Aitken RJ, Buckingham DW, Brindle J, Gomez E, Baker HW et al. Analysis of sperm movement in relation to the oxidative stress created by leukocytes in washed sperm preparations and seminal plasma. Hum Reprod 1995; 10: 2061-71.

77 Anderson D, Schmid TE, Baumgartner A, Cemeli-Carratala E, Brinkworth $\mathrm{MH}$ et al. Oestrogenic compounds and oxidative stress (in human sperm and lymphocytes in the Comet assay). Mutat Res 2003; 544: 173-8

78 Aitken RJ, Gordon E, Harkiss D, Twigg JP, Milne P et al. Relative impact of oxidative stress on the functional competence and genomic integrity of human spermatozoa. Biol Reprod 1998; 59: 1037-46.

79 Aitken RJ, Clarkson JS. Significance of reactive oxygen species and antioxidants in defining the efficacy of sperm preparation techniques. J Androl 1988; 9: 367-76.

80 Aitken RJ, Buckingham D, Harkiss D. Use of a xanthine oxidase free radical generating system to investigate the cytotoxic effects of reactive oxygen species on human spermatozoa. J Reprod Fertil 1993; 97: 441-50.

81 Lopes S, Jurisicova A, Sun JG, Casper RF. Reactive oxygen species: potential cause for DNA fragmentation in human spermatozoa. Hum Reprod 1998; 13: 896-900.

82 Potts RJ, Notarianni LJ, Jefferies TM. Seminal plasma reduces exogenous oxidative damage to human sperm, determined by the measurement of DNA strand breaks and lipid peroxidation. Mutat Res 2000; 447: 249-56.

83 Russo A, Troncoso N, Sanchez F, Garbarino JA, Vanella A. Propolis protects human spermatozoa from DNA damage caused by benzo[a]pyrene and exogenous reactive oxygen species. Life Sci 2006; 78: 1401-6.

84 Sierens J, Hartley JA, Campbell MJ, Leathem AJ, Woodside JV. In vitro isoflavone supplementation reduces hydrogen peroxide-induced DNA damage in sperm. Teratog Carcinog Mutagen 2002; 22: 227-34

85 Bungum M, Humaidan P, Axmon A, Spano M, Bungum L et al. Sperm DNA integrity assessment in prediction of assisted reproduction technology outcome. Hum Reprod 2007; 22: 174-9.

86 Collins JA, Barnhart KT, Schlegel PN. Do sperm DNA integrity tests predict pregnancy with in vitro fertilization? Fertil Steril 2008; 89: 823-31.

87 Aitken RJ, Fisher HM, Fulton N, Gomez E, Knox W et al. Reactive oxygen species generation by human spermatozoa is induced by exogenous NADPH and inhibited by the flavoprotein inhibitors diphenylene iodonium and quinacrine. Mol Reprod Dev 1997; 47: 468-82

88 Cemeli E, Schmid TE, Anderson D. Modulation by flavonoids of DNA damage induced by estrogen-like compounds. Environ Mol Mutagen 2004; 44: 420-6.

89 Dobrzynska MM, Baumgartner A, Anderson D. Antioxidants modulate thyroid hormone- and noradrenaline-induced DNA damage in human sperm. Mutagenesis 2004; 19: 325-30.

90 Muratori M, Piomboni $\mathrm{P}$, Baldi E, Filimberti E, Pecchioli $\mathrm{P}$ et al. Functional and ultrastructural features of DNA-fragmented human sperm. J Androl 2000; 21: 903-12.

91 Said TM, Agarwal A, Sharma RK, Thomas AJ Jr, Sikka SC. Impact of sperm morphology on DNA damage caused by oxidative stress induced by beta-nicotinamide adenine dinucleotide phosphate. Fertil Steril 2005; 83: 95-103.

92 Libman J, Gabriel MS, Sairam MR, Zini A. Catalase can protect spermatozoa of FSH receptor knock-out mice against oxidant-induced DNA damage in vitro. Int J Androl 2010; 33: 818-22. 
93 Griveau JF, Le Lannou D. Effects of antioxidants on human sperm preparation techniques. Int J Androl 1994; 17: 225-31.

94 Oeda T, Henkel R, Ohmori H, Schill WB. Scavenging effect of $\mathrm{N}$-acetyl-L-cysteine against reactive oxygen species in human semen: a possible therapeutic modality for male factor infertility? Andrologia 1997; 29: 125-31.

95 Verma A, Kanwar KC. Effect of vitamin E on human sperm motility and lipid peroxidation in vitro. Asian J Androl 1999; 1: 151-4.

96 Zheng RL, Zhang $\mathrm{H}$. Effects of ferulic acid on fertile and asthenozoospermic infertile human sperm motility, viability, lipid peroxidation, and cyclic nucleotides. Free Radic Biol Med 1997; 22: 581-6.

97 Calamera JC, Fernandez PJ, Buffone MG, Acosta AA, Doncel GF. Effects of long-term in vitro incubation of human spermatozoa: functional parameters and catalase effect. Andrologia 2001; 33: 79-86.

98 Chi HJ, Kim JH, Ryu CS, Lee JY, Park JS et al. Protective effect of antioxidant supplementation in sperm-preparation medium against oxidative stress in human spermatozoa. Hum Reprod 2008; 23: 1023-8.

99 Donnelly ET, McClure N, Lewis SE. Glutathione and hypotaurine in vitro: effects on human sperm motility, DNA integrity and production of reactive oxygen species. Mutagenesis 2000; 15: 61-8.

100 Donnelly ET, McClure N, Lewis SE. The effect of ascorbate and alpha-tocophero supplementation in vitro on DNA integrity and hydrogen peroxide-induced DNA damage in human spermatozoa. Mutagenesis 1999; 14: 505-12.

101 Hughes CM, Lewis SE, McKelvey-Martin VJ, Thompson W. The effects of antioxidant supplementation during Percoll preparation on human sperm DNA integrity. Hum Reprod 1998; 13: 1240-7.

102 Esteves SC, Sharma RK, Thomas AJ Jr, Agarwal A. Cryopreservation of human spermatozoa with pentoxifylline improves the post-thaw agonist-induced acrosome reaction rate. Hum Reprod 1998; 13: 3384-9.

103 Brennan AP, Holden CA. Pentoxifylline-supplemented cryoprotectant improves human sperm motility after cryopreservation. Hum Reprod 1995; 10: 2308-12.
104 Bell M, Wang R, Hellstrom WJ, Sikka SC. Effect of cryoprotective additives and cryopreservation protocol on sperm membrane lipid peroxidation and recovery of motile human sperm. J Androl 1993; 14: 472-8.

105 Wang R, Sikka SC, Veeraragavan K, Bell M, Hellstrom WJ. Platelet activating factor and pentoxifylline as human sperm cryoprotectants. Fertil Steril 1993; 60: 711-5.

106 Check DJ, Kiefer D, Katsoff D, Check JH. Effect of pentoxifylline added to freezing media on subsequent post-thaw hypoosmotic swelling test and other semen parameters. Arch Androl 1995; 35: 161-3.

107 Park NC, Park HJ, Lee KM, Shin DG. Free radical scavenger effect of rebamipide in sperm processing and cryopreservation. Asian J Androl 2003; 5: 195-201.

108 Askari HA, Check JH, Peymer N, Bollendorf A. Effect of natural antioxidants tocopherol and ascorbic acids in maintenance of sperm activity during freeze-thaw process. Arch Androl 1994; 33: 11-5.

109 Branco CS, Garcez ME, Pasqualotto FF, Erdtman B, Salvador M. Resveratrol and ascorbic acid prevent DNA damage induced by cryopreservation in human semen. Cryobiology 2010; 60: 235-7.

110 Li Z, Lin Q, Liu R, Xiao W, Liu W. Protective effects of ascorbate and catalase on human spermatozoa during cryopreservation. J Androl 2010; 31: 437-44.

111 Martinez-Soto JC, de Dioshourcade J, Gutierrez-Adan A, Landeras JL, Gadea J. Effect of genistein supplementation of thawing medium on characteristics of frozen human spermatozoa. J Androl 2010; 12: 431-41.

112 Thomson LK, Fleming SD, Aitken RJ, de Iuliis GN, Zieschang JA et al. Cryopreservation-induced human sperm DNA damage is predominantly mediated by oxidative stress rather than apoptosis. Hum Reprod 2009; 24: 2061-70.

113 Taylor K, Roberts P, Sanders K, Burton P. Effect of antioxidant supplementation of cryopreservation medium on post-thaw integrity of human spermatozoa. Reprod Biomed Online 2009; 18: 184-9.

114 Nallella KP, Sharma RK, Allamaneni SS, Aziz N, Agarwal A. Cryopreservation of human spermatozoa: comparison of two cryopreservation methods and three cryoprotectants. Fertil Steril 2004; 82: 913-8. 